\title{
Modernist Poetic Form
}

\section{Citation}

Albright, Daniel. 2007. Modernist poetic form. In The Cambridge Companion to TwentiethCentury English Poetry, ed. N. Corcoran, 24-41. Cambridge: Cambridge Univ. Press.

\section{Published Version}

http://dx.doi.org/10.1017/CCOL052187081X.003

\section{Permanent link}

http://nrs.harvard.edu/urn-3:HUL.InstRepos:3403052

\section{Terms of Use}

This article was downloaded from Harvard University's DASH repository, and is made available under the terms and conditions applicable to Open Access Policy Articles, as set forth at http:// nrs.harvard.edu/urn-3:HUL.InstRepos:dash.current.terms-of-use\#OAP

\section{Share Your Story}

The Harvard community has made this article openly available.

Please share how this access benefits you. Submit a story.

Accessibility 
Daniel Albright

Harvard University

\section{Modernist Poetic Form}

If Modernism implies experimentation with the limits of art, implies shocks and thrills beyond all previous bounds, then, in the matter of poetic form, the Victorians were more modernist than the Modernists themselves. As inventors of new stanza forms, as transgressors of prosodic boundaries, as explorers of new sonorities of verse, the Victorians and their colleagues in France and America were unsurpassable-the Modernist poets began their careers in a world in which the Victorians had already broken all the rules and developed strange and idiosyncratic new rules. It might be good to start this review of Modernist poetic form with a catalogue of some of the formal innovations of the nineteenth century, and their relation to the aesthetics of Modernism.

\section{Scrutiny of rhyme}

Rhyme has always been a somewhat dubious attribute of English poetry, partly because classical Greek and Latin poetry did not use it. Around 1603 Samuel Daniel felt he had to publish $A$ Defence of Ryme, because Campion and others had attacked it; and Milton began Paradise Lost (1674) with a note defending the rhymelessness of his epic: he called rhyme "to all judicious ears, triveal, and of no true musical delight; which consists onely in apt Numbers, fit quantity of Syllables, and the sense variously drawn out from one Verse into another, not in the jingling sound of like endings, a fault avoyded by the learned Ancients." By the nineteenth century the propriety of rhyming was no longer much of an issue-the canon of rhymed poetry was obviously too large and magnificent to be dispensed with-but poets kept experimenting with certain aspects of rhyme, particularly with the disturbing and disreputable aspects of rhyme that had led to Milton's condemnation. There is a moment in the second part of Goethe's Faust (1832) when Helen of Troy, newly awakened in the gothic North, hears rhymed poetry for the first time:

Lynceus. Already see the army tame, all their swords are blunt and lame, before that noble splendid form the sun itself seems dull, unwarm, and from that face a glory falls that makes all empty, and all null... . Helena. Many wonders I see, and many hear. Amazement strikes, questions come to mind. But first I wish instruction, why this man's speech rings so strange, amiable and yet so strange.

One sound, it seems, conforms itself to others, and if a word is conjoined to the ear, another comes, sweetly to fondle the first. (11. 9350-55, 9365-71)

The nineteenth-century poets sometimes wanted their contemporaries to hear rhyme with some 
of this same novelty, this uncanny sweetness-to hear rhyme as if no one had ever heard rhyme before.

Robert Browning had a gift for making rhyme feel fresh, obtrusive:

Nor brighter was his eye, nor moister

Than a too-long-opened oyster ...

This is from a children's poem, "The Pied Piper of Hamelin" (1842), but extremely conspicuous rhymes usually sound child-like or comical; the Victorian age is the great age of nursery rhymes, limericks, and operettas:

About binomial theorem I'm teeming with a lot o' news-

With many cheerful facts about the square of the hypotenuse.

(W. S. Gilbert, The Pirates of Penzance, 1879)

In general poets have avoided too ingenious or too loud rhymes for fear of embarrassment; where technique calls attention to itself the possibility of doggerel is always strong.

Browning, a boisterous introvert, had no qualms about his moister oysters, but he also experimented with the opposite sort of virtuoso performance: extremely inconspicuous rhymes. Anyone who teaches "My Last Duchess" can discover Browning's success by asking the students about the poem's meter: almost everyone remembers the poem as blank verse, when in fact it consists of rhymed couplets, enjambed with such nonchalance, such sprezzatura, that you hear the poem without rhymes. Tennyson played the opposite trick, by writing lyrics in blank verse, such as "Tears, idle tears," that linger in the memory with the fragrance of rhyme, even though the unrhymed stanzas are bound together by repetition, assonance, and refrain.

The most searching and influential work with rhyme, however, was that of the American poet Emily Dickinson:

I heard a Fly buzz-when I died-

The Stillness in the Room

Was like the Stillness in the Air-

Between the Heaves of Storm- (\#465, ca. 1862)

Dickinson's slant rhyme derives its effect from the hymn-like strictness of meter: where the meter is simple, strong, and familiar, the false rhyme of room/storm makes itself heard emphatically. An early editor in fact rewrote the second line to read "The stillness round my form" to "improve" the poem. But the very discord of the rhyme creates a kind of shiver, appropriate to the poem's macabre theme: Dickinson's taste for dissonance, unprepared modulation, became part of the general taste of Modernism.

Is there a Modernist style of rhyming? The Modernist preoccupation with self-conscious technique, artifice that exposes its own artificiality at every turn, sometimes turns into a kind of preciosity:

Should I, after tea and cakes and ices, Have the strength to force the moment to its crisis?

(Eliot, "The Love Song of J. Alfred Prufrock," 1911) 
Both Eliot and Pound inherited a certain strain of brittle rhyme, often using arcane or scientific vocabulary, from the French fin-de-siècle ironists, such as Jules Laforgue:

He had passed, inconscient, full gaze, The wide-banded irides

And botticellian sprays implied

In their diastasis ... (Pound, "Mauberley (1920)")

Non, je resterai seul, ici-bas,

Tout à la chère morte phtisique,

Berçant mon cœur trop hypertrophique

Aux éternelles fugues de Bach.

[No, I huddle in my solitude,

Devoted to the phthisic dead

While my heart hypertrophied

Cradled in Bach's eternal fugues.]

(Laforgue, "Complainte de l'organiste de Notre-Dame de Nice")

These poems by Laforgue, Pound, and Eliot all concern ineffectual personages, personages permanently at a loss; and the fussy diction, the funny finical rhyming, suggest their incapacity to deal with the asperities of the twentieth century. Rhyming is read as a retreat, a cowering before modern life. In some sense both Prufrock and Mauberley are personifications of rhyme itself, of passé modes of writing poems.

And yet, there is a great deal of rhyming poetry in the Modernist movement; rhyme is part of the Tradition that the Individual Talent embraces but embraces at arm's length. The halfrhyme often seems a satisfying way of respecting the tension between the Old Dispensation of English poetry and the New. For example, look at the opening lines of Yeats's "The Second Coming" (1919):

Turning and turning in the widening gyre

The falcon cannot hear the falconer;

Things fall apart; the centre cannot hold;

Mere anarchy is loosed upon the world ...

This poem is composed in blank verse, and yet these opening lines almost fall into couplets-and in fact when Yeats began writing this he envisaged a poem in rhyme. There is a ghost of order; but the poem is falling into rhymelessness, just as the falconer is losing control of the falcon. Lapsing rhymes suggest disorder more strongly than no rhymes at all.

Another form of dissonant Modernist rhyme, invented by the war poet Wilfred Owen and developed by Auden, consists of repeating whole syllables while altering the vowel:

It seemed that out of the battle I escaped

Down some profound dull tunnel, long since scooped

Through granites which Titanic wars had groined. 
Yet also there encumbered sleepers groaned ... (Owen, "Strange Meeting," 1918)

Acquire that flick of wrist and after strain

Relax in your darling's arms like a stone,

Remembering everything you can confess,

Making the most of firelight, of hours of fuss ...

(Auden, "Venus Will Now Say a Few Words," 1929)

Such poems gain momentum from the continual discoloration of vowel-sounds; Owen's poem is about imagining one's own death, and Auden's concerns blind evolutionary process-in both cases the phonic distortion becomes an image of unpleasant mutation. Auden was a master of rhyme as a form of dissonance:

I cannot grow;

I have no shadow...

I cannot err;

There is no creature ... (“Anthem for St. Cecilia's Day," 1940)

The technical term for this sort of rhyme is anisobaric-the rhyming of a stressed syllable with an unstressed. It has usually been considered a comic device or a technical fault; but just as, in music, Arnold Schoenberg labored to emancipate the dissonance, the Modernist poets found exotic sonorities in the land of error.

\section{Scrutiny of meter}

"To break the pentameter, that was the first heave," Pound tells us in Canto 81, but, from the beginning of Modern English, the pentameter is continually being broken and re-formed. The ice can't keeping thawing unless it refreezes from time to time.

In every age there have been poets with a strong taste for prosody remote from the daDUM iambics that come so naturally to a language in which most sentences begin with an unstressed article or pronoun followed by a word accented on the first syllable. Here is a passage from John Donne's Satyre IV (?1590s):

He knowes who'hath sold his land, and now doth beg

A licence, old iron, bootes, shooes, and egge-

shels to transport ...

He with home-meats tries me; I belch, spue, spit, Looke pale, and sickly, like a Patient; Yet ...

Donne more or less observes the ten-syllable rule for heroic verse, but he deliberately makes the movement of the verse harsh, jarring, appropriate for the mangled ethics of the courtier in question. The iambic pulse is strongly disrupted by great clots of stressed syllables: "I belch, spue, spit, / Looke pale"; "bootes, shooes, and egge- / shels"-note how he splits the word eggshells in half, so thick and broken is the verbal texture. To say it out loud is to feel as if you're chewing gristly meat. In the eighteenth century Alexander Pope felt impelled to rewrite this in decent heroic couplets, by ironing out all the knots of rhythm: 
As one of Woodward's patients, sick, and sore,

I puke, I nauseate--yet he thrusts in more ...

Pope pukes and nauseates in even iambs; he doesn't vomit out undigested syllables.

But again the great experimentalists in prosody are the Victorians, despite their reputation for genteel conservatism. Matthew Arnold was a professional school-inspector and a strong advocate for educational reform; he was also sporadically engaged in the reform of the meters of English poetry:

When the white dawn first

Through the rough fir-planks

Of my hut, by the chestnuts,

Up at the valley-head,

Came breaking, Goddess!

I sprang up, I threw round me

My dappled fawn-skin ... ("The Strayed Reveller," 1849)

This is recognizable as verse not because it can be broken down into a regular sequence of metrical feet, but because short phrases, often prepositional phrases, function as pseudo-feet, creating a chant-like sound. In most verse there is a tension between syntax and meter: the syntax spills over the neat cuts between one foot and the next, between one line and the next; but Arnold manages to make syntax itself do the work of meter, by parceling out the long sentence into choppy exclamatory units. On the one hand this gives an antique feel to the poem, as if it were a literal translation of some non-existent Greek original; on the other hand the poem seems quite advanced in its organicism, its perfect identity of meter and syntax, form and content.

Organicism, specifically the organicist desire to make sound conform to sense, explains much of the history of prosodic experiment. There has always been felt a certain desire to bend the rules of meter in order to accommodate the kinesthesis of the poem's subject-Pope gives some handy advice on this theme:

When Ajax strives some rock's vast weight to throw,

The line too labours, and the words move slow:

Not so when swift Camilla scours the plain,

Flies o'er th' unbending corn, and skims along the main ...

(Essay on Criticism, 1711)

Not only does Pope expand the last line to a hexameter, but he contracts four syllables (over the un-) to two in order to suggest how Camilla's gossamer foot barely grazes the ground. Samuel Johnson quoted this passage in his Life of Pope (1781), commenting, sourly, "Beauties of this kind are commonly fancied, and, when real, are technical and nugatory, not to he rejected and not to be solicited."

But Pope's slow Ajax and swift Camilla are both hopeless moderates compared to the some of the experiments in poetic dynamism in the nineteenth century. In America Walt Whitman watched two eagles whirling together in air, and wrote a whirl-shaped poem in response: 
Skirting the river road, (my forenoon walk, my rest,)

Skyward in air a sudden muffled sound, the dalliance of the eagles,

The rushing amorous contact high in space together,

The clinching interlocking claws, a living, fierce, gyrating wheel,

Four beating wings, two beaks, a swirling mass tight grappling,

In tumbling turning clustering loops, straight downward falling ...

("The Dalliance of the Eagles," 1880)

Here strings of present participles and participial phrases act as pseudo-feet, do the work of meter by organizing the rhythm around forms of energy. Especially noteworthy is the phrase swirling mass tight grappling, a sort of involved participial loop, a single huge foot so emphatic that the only unstressed syllables are the -ing endings. Everywhere the syntax wheels around without terminating in a clear subject-verb-object pattern: in fact in the entire poem there isn't a single finite verb-in the participles, noun and verb are all balled up together, just as the eagles are all balled up together. The speech-unit is the syntax-unit; there is no meter than can be abstracted from the actual sonorities of the specific words. There is recurrence, but unpredictable recurrence; the meter of the poem is more a kind of weather than a kind of dance.

It is useful to compare Whitman's eagles with an equally radical bird, Gerard Manley Hopkins's falcon-here are the first eight lines as Hopkins scanned them:

I: cáught this $\mid$ mórning | mórning’s | mínion, | kíng-

dom of | dáylight’s | dáu(phin), dapple- | dáwn-drawn | Fál(con), in his | ríding

Of the | ró(lling) level | únder | néath (him) steady | áir, and | stríding |

Hígh there, how he $\mid$ rúng upon the $\mid$ réin of a $\mid$ wímpling | wíng

In his | écstasy! Then | óff, | óff | fórth on | swíng,

As a | skáte's (heel) sweeps $\mid$ smóoth on a | bów-bend: the | húrl and | glíding

Re | búffed the | bíg | wínd. My | héart in | híding |

Stírred for a $\mid$ bírd,-the a | chíeve of, the | mástery of the | thíng! | ("The Windhover," 1876)

The texture of "The Windhover" is a hovering, not an explicit stating: nouns are bent into adjective-compounds (dapple-dawn-drawn), present participles usurp the place of nouns for many of the rhyme-words, for in a poem such as this, more like an electromagnetic field than like a piece of parsable grammar, the subject is energy-what Hopkins called instress, the flashing-forth of God's creative force from the falcon.

The reticent Jesuit priest Hopkins was influenced by the pantheist pansexual WhitmanHopkins once wrote, "I always knew in my heart Walt Whitman's mind to be more like my own than any other man's living. As he is a great scoundrel this is not a pleasant confession" (18 Oct. 1882, to Robert Bridges). But Hopkins went further than Whitman in trying to notate his poems as a sort of musical score. The sonnet form is twisted and pulled by the rhythm-what Hopkins 
called Sprung Rhythm (every foot begins with a stressed syllable, and the unstressed syllables, of variable number, are crowded together so that each foot takes exactly the same amount of time to pronounce): the isochronous line introduces accelerations and hesitations, emphases, cuts, turnsthe very form of the bird's flight, its careening, its whistling around enjambements, is incarnate in the word-flow. Compared to Whitman's savage eagles, the falcon seems to have little ornithological existence: it is a pretext for impressing onto the syllables a feeling for a certain sort of motion through the air.

Hopkins's poetry was almost unknown until1918, long after his death, when his friend Robert Bridges published an edition of his work. Though Hopkins lived as a Victorian, his fame was that of a Modernist, since his poems, coming to light at the end of the Great War, seemed to have something of the jazz and pizzazz, the linguistic torsion, of Edith Sitwell and other experimentalists. His notion of rethinking meter according to musical form also found congenial ears: the three tenets of Imagism, the movement founded in 1912 by Pound, Richard Aldington, and Hilda Doolittle ("H.D.") were:

1. Direct treatment of the 'thing' whether subjective or objective.

2. To use absolutely no word that does not contribute to the presentation.

3. As regarding rhythm: to compose in the sequence of the musical phrase, not in sequence of a metronome. (Pound, Literary Essays [New York: New Directions, 1968], p. 3)

Pound's dislike of iambs was strong. In his maturity, he only rarely tried to write regular English verse, and when he did he usually stiffened the texture with lots of spondaic substitutions, as in the parody of the Rubáiyát stanza at the end of Canto LXXX (1946):

Tudor indeed is gone and every rose,

Blood-red, blanch-white that in the sunset glows

Cries: "Blood, Blood, Blood!" against the gothic stone

Of England, as the Howard or Boleyn knows.

But often the Modernists overtly rejected traditional English meters, and looked elsewhere for their rhythms. The main sources for alternative rhythmic schemes were: (1) Old English; (2) Greek and Latin; (3) Japanese and Chinese; and (4) none of the above-pure intuition.

\section{Alternative meters (1): Old English}

There is a strong Modernist tendency to seek for authenticity in the archaic-to try to ground language in some primal linguistic act, such as the Sanskrit thunder-word $D A$ in Eliot's The Waste Land. So it is not surprising that they might tend to reform meter by looking at the earliest extant poetry in the English language, the poetry written in Anglo-Saxon from the eighth to the eleventh century, before the Norman Conquest of 1066 broke the Germanic spine of the language by imposing French vocabulary and syntax.

The corpus of Old English poetry was recovered slowly. A fascination with Germanic and Celtic archaism can be seen in the eighteenth-century verse of Gray, Chatterton, and Macpherson ("Ossian"), but among the Victorians the scholarly study of the ancient language started to influence poetry in many ways. Some Victorians felt that English had been weakenedmade soft, tame, and abstract-by its adoption of French words, French diction; Old English 
seemed hard, swift, concrete. As Hopkins wrote Bridges:

Rev. Wm. Barnes ... has published a "Speech craft of English Speech" = English Grammar, written in an unknown tongue, a sort of modern Anglosaxon ... He does not see the utter hopelessness of the thing. It makes one weep to think what English might have been; for in spite of all that Shakspere and Milton have done with the compound I cannot doubt that no beauty in a language can make up for want of purity. In fact I am learning Anglosaxon and it is a vastly superior thing to what we have now. But the madness of an almost unknown man trying to do what the three estates of the realm together could never accomplish! He calls degrees of comparison pitches of suchness; we ought to call them so, but alas! (To Robert Bridges, 26 Nov. 1882)

Hopkins thought that Barnes had gone too far, but nonetheless pined for an unfallen English, with its old purity and precision somehow restored.

So did other poets, who became fascinated with the meter of Old English-a pattern of paired half-lines of two stressed syllables each (and a varying number of unstressed syllables), bound together by alliteration. Tennyson's son was a scholar of Old English, and published a prose version of The Battle of Brunanburh (AD 937) that his father consulted in his famous verse translation:

Bow'd the spoiler,

Bent the Scotsman,

Fell the ship-crews

Doom'd to the death.

All the field with blood of the fighters

Flow'd, from when the first the great

Sun-star of morning-tide

Lamp of the Lord God

Lord everlasting,

Glode over earth till the glorious creature

Sank to his setting.

Tennyson doesn't obey the strict rules of alliteration, but he certainly provides a good deal of itsometimes rather too much. He imitates some of the gnarly, twisty quality of the syntax with his inversions (Bow'd the spoiler, / Bent the Scotman); and by using glode as the past tense of glide he delves deep into the prehistory of the modern word. The irregular, rough-hewn texture of Old English verse is suggested, though Tennyson tends to default to a dactyl + trochee meter (Lámp of the| Lórd God; Lórd ever- | lásting; Sánk to his | sétting).

Ezra Pound knew Robert Bridges, and inherited something of Bridges' love of extending English vocabulary through archaic words and meters. Bridges cackled with delight at some of the strange words in Pound's early poetry, as Pound remembered in Canto LXXX:

"forloyn" said Mr Bridges (Robert)

"we'll get 'em all back"

meaning archaic words 
And in 1911 Pound published the most influential of all translations of Old English poetry, "The Seafarer":

Bitter breast-cares have I abided, Known on my keel many a care's hold, And dire sea-surge, and there I oft spent Narrow nightwatch nigh the ship's head While she tossed close to cliffs. Coldly afflicted ...

Here is a compelling combination of immediacy and artifice-language that cuts near the bone, and literal imitation of the compound epithets, called kennings, that mark Old English verse. The poem provides a shiver both with its icy subject matter and with its clash, jar, of stressed syllables abutting.

This use of Old English to strip poetry of decorative elements, to simplify into strangeness, was explored throughout the twentieth century-from Auden's "The Wanderer" ("Doom is dark and deeper than any sea-dingle") through Seamus Heaney's distinguished translation of Beowulf.

\section{Alternative meters (2): Greek and Latin}

Poets and critics have had much difficulty in trying to establish a clear relation between the Germanic elements of English prosody, based on stress, and the classical elements, based on quantity. Greek and Latin words had stresses, but the meter was determined not by how loudly you pronounced a syllable, but by how much time you took in pronouncing a syllable. So a classical line is conceived as an array of half-notes and quarter-notes, whereas a Germanic line is conceived as an array of strong and weak accents.

It is possible, of course, to transpose the classical feet-iambs, trochees, anapests, and so forth-from a quantitative to an accentual system, and English poetry has thrived by adopting that very procedure. But it works well only with classical meters that don't contain too many long or short syllables in a row: we hear little in English poetry of such feet as the molossus (- --$)$ or the bacchius $(---)$ or the tribrach $(---)$ because the rhythms of the language resist them. A sequence of consecutive strong syllables will tend to be read with certain weakenings in the middle, and vice versa. When the Countess of Winchilsea wrote, "Faintly the inimitable rose," she came about as close as any poet could come to writing a line with a strong stress at each end and seven unstressed syllables in the middle; and yet stresses keep popping up in regular alternation, whether bidden or not.

But from the beginnings of Modern English, poets have tried to contrive ways of forcing English feet into classical shoes that don't easily fit. In 1602 Thomas Campion offered this sample of the "English Sapphick"-"The first three verses therefore in our English Sapphick are merely those Trochaicks ... excepting only that the first foote of either of them must ever of necessity be a Spondee, to make the number more grave":

Fáiths púre | shíeld, the | Chrístian | Diána, Énglánds | glóry | crównd with | áll de- | vínenesse, Líve lóng | wíth tri- | úmphs to | blésse thy | péople

Át thy | síght tri- |úmphing. (The Works of Thomas Campion, ed. Walter R. Davis [London: Faber and Faber, 1969], p. 309) 
It isn't easy to read the third verse according to Campion's desired scansion.

Milton made similar experiments with classical meters, and later Tennyson ("O mightymouth'd inventor of harmonies ... God-gifted organ-voice of England" in "Milton: Alcaics"). In almost all of these cases, the reader notes the abundance of spondees and dactyls-feet that begin with a stomp, feet that have a heavy but uncertain tread, because normal expectations of kinesis are violated. In Modernist imitations of classical meters, this provisionality of footing sometimes itself becomes a theme:

See, they return; ah, see the tentative

Movements, and the slow feet,

The trouble in the pace and the uncertain

Wavering!

See, they return, one, and by one,

With fear, as half-awakened;

As if the snow should hesitate

And murmur in the wind, and half turn back;

These were the "Wing'd-with-Awe,"

Inviolable.

This is Pound's "The Return" (1912), concerning the return of the Greek gods, and the return of the Greek meters as well: just as the gods struggle to realize themselves in an uncongenial world, so the meters struggle toward clarity of rhythm without quite attaining it. Yeats considered this one of the few successful poems written in free verse, but also felt that "he has not got all the wine into the bowl, that he is a brilliant improvisator" (The Oxford Book of Modern Verse, ed. W. B. Yeats [London: Oxford University Press, 1966], p. xxvi). But perhaps the poem is about not getting all the wine in the bowl, about the ways in which English words keep squirming out of Greek metrical patterns. The poem is full of third epitrites $(--\cup-)$, but the footing is slippery, treacherous.

Classical prosody and Germanic alliterative verse have little in common. And yet, in the canon of Modernist experiments, they sometimes have a similar sonority. The trochee, the spondee, and the dactyl are the natural alternatives to the iambic and anapestic rhythms of normal English verse. The snow-shower of Greek gods in "The Return" is somewhat different from the "hail-scur" that troubles the hero of the "The Seafarer"; but rhythms that deviant strongly from iambic pentameter tend to follow similar paths of deviation, if they are to remain rhythms at all.

\section{Alternative meters (3): Chinese and Japanese}

A certain tendency toward the gnomic and fragmentary can be found in late nineteenthcentury poetry, particularly in America:

You tell me this is God?

I tell you this is a printed list, 
A burning candle, and an ass. (Stephen Crane, War is Kind X)

To make a prairie it takes a clover and one bee,

One clover, and a bee,

And revery.

The revery alone will do,

If bees are few. (Emily Dickinson, \#1755)

This tendency toward the spare, severely reductive, started to be understood as a sort of Orientalism as the poetry of Japan, especially the seventeen-syllable haiku form, became known in the West. Crane takes God and keeps subtracting, until nothing is left but list, candle, and ass; Dickinson performs a subtraction in two stages, until nothing is left but reverie.

The Imagists and Vorticists in Pound's circle adopted a self-consciously Asiatic aesthetic, working toward meters that might be called meters of deletion. In his September 1914 Vorticism article, Pound quotes the "substance" of a Japanese haiku:

The fallen blossom falls back to its branch:

A butterfly. (Ezra Pound and the Visual Arts, ed. Harriet Zinnes [New York: New Directions, 1980], p. 205)

Then he tells a story about how he made a long poem about seeing beautiful faces on a subway platform, but kept paring down this work "of second intensity" until he had the following "hokku-like sentence":

$\begin{array}{ll}\text { The apparition of these faces } & \text { in the crowd } \\ \text { Petals on a wet, black } & \text { bough }\end{array}$

Only in its first two printings did the poem appear without punctuation and with gaps in the lines. In this original form, the six elements of the poem look like erratic feet, or like phrase-units compressed into something like ideograms.

Chinese poetry does not typically have the stark brevity of Japanese, but Chinese also influenced the rhythms of Modernist poetry. Pound went to trouble to publish and to keep in print Ernest Fenollosa's essay The Chinese Written Character as a Medium for Poetry:

A true noun, an isolated thing, does not exist in nature. Things are only the terminal points, or rather the meeting points, of actions, cross-sections cut through action, snap-shots. Neither can a pure verb, an abstract motion, exist in nature. The eye sees noun and verb as one: things in motion, motion in things, and so the Chinese conception tends to represent them....

The Chinese have one word, ming or mei. Its ideograph is the sign of the sun together with the sign of the moon. It serves as verb, noun, adjective. Thus you write literally 'the sun and moon of the cup' for 'the cup's brightness.' Placed as a verb, you write 'the cup sun-and-moons,' ... i.e. shines. (Ernest Fenollosa, The Chinese Written Character as a Medium for Poetry [San Francisco: City Lights Books, 1969], pp. 10, 18)

This doctrine tended to turn Whitman into a Chinese poet in spite of himself: Whitman's way, in 
"The Dalliance of the Eagles," of smearing nouns and verbs into a sort of participial soup is, by Fenollosa's definition, ideogrammic. Pound's Vorticist poetry often shows a Whitmanesque fondness for present participles, as in "Dogmatic Statement on the Game and Play of Chess: Theme for a Series of Pictures":

Red knights, brown bishops, bright queens

Striking the board, falling in strong "L's" of colour,

Reaching and striking in angles,

Holding lines of one colour...

Their moves break and reform the pattern:

Luminous greens from the rooks,

Clashing with "x's" of queens ... (Ezra Pound and the Visual Arts, pp. 153-54)

The participles again create a dynamic that spills out of normal sentence patterns; and the " $L$ 's" and the "x's" are alphabet-letters made to do the work of ideograms, as if Pound were trying to make letter-shapes embody the vectors of the chess pieces.

\section{Alternative meters (4): free verse}

The prose poem was invented in the nineteenth century, by Baudelaire, Mallarmé, and other French poets; and no verse could be freer than Whitman's. This left the Modernists in the oddly retrograde position of having to defend a poetic manner that was less radical than their predecessors'. Eliot published a single prose poem, "Hysteria," and Auden considered that his prose text "Caliban to the Audience" was the best thing he ever wrote; but for the most part the Modernists tried to defend a middle position, somewhere between the scannable and the unscannable. Robert Frost compared free verse to playing tennis without a net; and in his earliest reprinted essay, Eliot claimed that

Vers libre does not exist ... the most interesting verse ... has been done either by taking a very simple form ... and constantly withdrawing from it, or taking no form at all, and constantly approximating to a very simple one. It is this contrast between fixity and flux, this unperceived evasion of monotony, which is the very life of verse. (To Criticize the Critic [New York: Farrar, Straus, 1965], pp. 183, 185)

We can take this as a typical Modernist position on free verse. In 1917 Pound quoted with approval Eliot's "No vers is libre for the man who wants to do a good job," and added, "I do not think one can use to any advantage rhythms much more tenuous and imperceptible than some I have used" (Literary Essays, pp. 12-13). Even William Carlos Williams, hostile to Eliot in so many areas, agreed in this disparagement of free verse:

free verse since Whitman's time has led us astray. ... Relativity gives us the cue. So again, mathematics comes to the rescue of the arts. ... We have today to do with the poetic, as always, but a relatively stable foot, not a rigid one. ... Without measure we are lost. (Selected Essays [New York: New Directions, 1969], pp. 339-340)

Williams's notion of a poetic unit consisting of an intuitive and variable foot seems to rest on something difficult to understand: unstable measurement. To cite the authority of Einstein does 
not solve the difficulty. On the other hand, some of Williams's best poems are fairly easy to understand as approximations to or evasions of traditional meters:

In Breughel's great picture, The Kermess, the dancers go round, they go round and around, the squeal and the blare and the tweedle of bagpipes, a bugle and fiddles tipping their bellies, (round as the thicksided glasses whose wash they impound) ... (“The Dance," 1944)

The poem begins in clear amphibrachs $(\cup-\cup)$, but tipsies off into dactyls, as Williams erratically cuts the line breaks and caesuras to begin with stressed syllables; the poem is an exercise in eccentricity, for the meter is a prolonged toppling. The idea of dance, a dance liberated from strict beats, governs many of the wildest passages of Modernist poetry. Stravinsky wrote ballets in which (in certain passages) every bar has a different time signature; and Edith Sitwell, inspired by Stravinsky's Petrushka (1911) and Liszt's transcendental études, wrote poetry in which the meter frisks and syncopates beyond any Shakespearean rag or Tennysonian cakewalk:

Watched the courses of the breakers' rocking horses and with Glaucis, Lady Venus on the settee of the horsehair sea!

Where Lord Tennyson in laurels wrote a gloria free, In a borealic iceberg came Victoria; she

Knew Prince Albert's tall memorial took the colors of the floreal

And the borealic iceberg; floating on they see ... ("Hornpipe," from Façade, 1922)

Sitwell claimed that "The poems in Façade are abstract poems--that is, they are patterns in sound. They are ... virtuoso exercises in technique of extreme difficulty" (The Canticle of the Rose Poems: 1917-1949 [New York: Vanguard Press, 1949], p. xii). The notion of pure rhythm, rhythm liberated from every burden of meaning, is one of many Modernist dreams of the artistic absolute.

\section{Scrutiny of the stanza}

The idea that a poem should shape itself around the thing it represents is old-George Herbert's winged-shaped "Easter Wings" (1633) is a famous example-but in the nineteenth century this notion of poem-icon was taken to stunning lengths. In Victor Hugo's "Les Djinns" (1829) the first stanza consists of lines of two syllables each, the second three syllables, until a nine-syllable stanza is reached, at which point the stanzas start to contract: the djinns come in a whirlwind, and in a poem shaped like a whirlwind. Among the Modernists, the notion of a stanza that embodies the dynamic form of its subject matter is strong: there is no exact English equivalent of Apollinaire's Calligrammes, in which the lines twist and curl, spin themselves into recognizable shapes, but Pound's Canto XC (1955) has a passage shaped like a vortex:

thick smoke, purple, rising

bright flame now on the altar

the crystal funnel of air 
out of Erebus, the delivered,

Tyro, Alcmene, free now, ascending

e i cavalieri

ascending,

no shades more,

lights among them, enkindled...

And Eliot's favorite passage from his Waste Land (1922) was a song about drops of water consisting of audible drips:

If there were rock

And also water

And water

A spring

A pool among the rock

If there were the sound of water only ...

Drip drop drip drop drop drop drop

But there is no water

The poem strives to configure itself into the shape, the sound, of the water, the absent water.

But there is another side to Modernist poetics, a side that questions every possibility of creating an identity between form and content. Instead, some poets allege that there is no relation between form and content. Auden partly resisted Paul Valéry's theory that all poetic form is arbitrary:

Valéry overstresses, I think, the arbitrariness of poetic formal restrictions ... If they really were purely arbitrary, then ... the experience which every poet has had, of being unable to get on with a poem because he was trying to use the "wrong" form ... would be unknown. (Forewords and Afterwords [New York: Random House, 1973], p. 364)

On the other hand, Auden was evidently determined to try every poetic form known to the human race, for the sheer exhilaration of technical challenge. Here is his attempt to imitate the Old Norse form known as the drottkvaett, a form so muscle-bound that a poet, in English, finds it almost impossible to say anything at all:

Hushed is the lake of hawks,

Bright with our excitement,

And all the sky of skulls

Glows with scarlet roses ...

(Secondary Worlds [New York: Random House, 1968], p. 68)

Like Sitwell's experiments with abstract rhythms, this English drottkvaett seems an experiment with an abstract stanza form, an object for pure play. So-Modernism vacillates between incarnational and disengaged ideals of poetic form.

Sometimes it even seems as if poets have outgrown the traditional forms and their strong music, and need to cast them aside: 
Comets weep and Leonids fly

Hunt the heavens and the plains

Whirled in a vortex that shall bring

The world to that destructive fire

Which burns before the ice-cap reigns

That was a way of putting it-not very satisfactory,

A periphrastic study in a worn-out poetical fashion ... (Eliot, "East Coker," 1940)

But Eliot prints the stanza, even in the act of repudiating it.

Here Eliot adjusts his persona in the very act of adjusting poetic form: a critical, captious weary voice speaks in long prosaic lines, undoing the confident prophet who spoke in rhymed tetrameter. A poem that mixes disparate poetic forms becomes a tracing of the various modalities of a single sensibility-its continual modulation from one persona to the next. This sort of mixture is, I think, one of the contributions of Modernism to the art of poetry.

The original title of The Waste Land was He do the Police in Different Voices, and Eliot's more ambitious poems are continuous acts of vocal impersonation, in which different voices adopt different sorts of poetic stanzas. In his Ph.D. dissertation, Eliot wrote that the human self is essentially incoherent and multiple:

Reality contains irreducible contradictions and irreconcilable points of view.

the life of the soul does not consist in the contemplation of one consistent world but in the painful task of unifying (to a greater or less extent) jarring and incompatible ones, and passing, when possible, from two or more discordant viewpoints to a higher which shall somehow include and transcend them. (Knowledge and Experience in the Philosophy of F. H. Bradley [New York: Farrar, Straus, 1964], pp. 112, 147-48)

The Modernist sense of plurality of the self finds its natural expression in the rapid passage from one stanza-form to another. Even Yeats wrote that, as he considered the complete array of human personalities, that it was like staring "at my own form ... in a room full of mirrors" $(A$ Vision [New York: Macmillan, 1961], p. 214); and in the poem "Vacillation" Yeats changes stanza-form as he changes mood, changes self. When Yeats writes a sonnet, he adopts the persona of a sonnet-writer, such as John Donne:

A sudden blow: the great wings beating still

Above the staggering girl, her thighs caressed ... (Yeats, "Leda and the Swan")

Batter my heart, three-person'd God, for you

As yet but knock, breathe, shine, and seek to mend ... (Donne, "Holy Sonnets" XIV)

Modernist poetic form generally poises itself between extreme systemlessness and radical resystematization. The poet manipulates forms, but noncommitally-the form is at best a provisional resting-place amid a constant shifting, transmutating. In "The Auroras of Autumn" (1947), Wallace Stevens wrote of "form gulping after formlessness"-and a Modernist stanza is often less like a perfected design than like the outline of an animal in the python's belly, slowly 
losing its contour. Or as Robert Frost put it (Complete Poems [New York: Holt, Rinehart, 1958], p. viii), "Like a piece of ice on a hot stove the poem must ride on its own melting." 